Justyna Matys

\title{
A NEW REGULATION ON STATE TREASURY RESPONSIBILITIES FOR THE DAMAGE DONE WHILE EXECUTING OFFICIAL AUTHORITY
}

\section{State responsibility in historical perspective}

Current legislation of State Treasury responsibilities in the Polish Civil Code (CC) in force from 1st Sept. 2004. From that date, the Act of amending the Civil Code and certain other laws, ${ }^{1}$ which adapted the rules of the Civil Code to Art. 77, par. 1 of the Constitution, ${ }^{2}$ containing a general rule of liability for the exercise of official authority ${ }^{3}$.

Under Polish law, the principle that the state is liable for damage caused to the citizens was first introduced in the Constitution of 17th March 1921 (the March Constitution), the first constitution adopted after Poland regained independence. It is remarked that The Republic of Poland was the first European country with 'constitutionalisation' which entitled compensation for damage caused by the operation of public authority ${ }^{4}$. The provision of Art. 121 stated: "Every citizen has the right to compensation for damage which was caused to him by state, civil or military authorities through illegal official activities or against service obligations. Responsible for the damage is the state together with other bodies; bringing an action against the State and against the officials is not dependent upon the authorization of a public authority. Likewise, the responsibility lies on municipalities and other government bodies and their authorities. Carrying out this policy is defined by separate laws". Unfortunately, the pre-war legislature has not adopted provisions of laws through which victims could claim compensation. In subject literature,

The Act of 17.6.2004, Journal of Laws No. 162, item 1692.

The Polish Constitution of 2.4.1997, Journal of Laws No. 78, item 483 with further amendments.

See: art. 77.1 of the Constitution: „Everyone shall have the right to compensation for any harm done to him by any action of an organ of public authority contrary to law."

4

See: E. Bagińska, Odpowiedzialność odszkodowawcza za wykonywanie władzy publicznej, Warszawa 2006 r., S. 143, P. Dzienis, Odpowiedzialność cywilna władzy publicznej, Warszawa 2006, p. 35, M. Safjan, K.J. Matuszyk, Odpowiedzialność odszkodowawcza władzy publicznej, Warszawa 2009, p. 19. 
doubts have arisen whether Art. 121 of the Constitution could be used directly. ${ }^{5}$ The most quoted statement of the Supreme Court of this period is the decision of 16 December 1927, in which the Court stated that "damage caused by a State officer, even in the public service, causes the State's responsibility if it is not about the acts of the authority 6 ". In the interwar period, courts differentiated activities for those of a commanding character, for which the country bore no responsibility and acts in the sphere of dominion where the damage could be compensated.

However, the actual introduction of the principle of State liability for damage caused by the exercise of public authority, was of great importance. For centuries, the rule in force said that the one who exercises sovereign authority can not be responsible for damages related to its implementation in accordance with the following principle: "The King can't do wrong". The creators of the Constitution recognized the necessity of a different approach so that victims would not have to bear the same risk of damage from the exercise of public authority.

In the early postwar period, the possibility of claims for compensation for prejudice resulting from the exercise of public authority was excluded. The Supreme Court, in its decision of 31 October 1950, stated that "if a specific provision does not provide otherwise, the State is not liable for damage caused by the executing authority of the State acting as a coercive apparatus, which does not exclude the possibility that perceiving this as the irresponsibility of the State for its authorities also in other cases, where the public interest does not allow the limitation of the operational efficiency of those bodies" ${ }^{7 "}$. At the same time it should be noted that in the economic sphere, the state bore responsibility as a legal person for the actions of their bodies.

For this problem an essential act is the one of 15 th November 1956, on responsibility for damages caused by State officers. ${ }^{8}$ The Act provided the legal claims, constituted an independent basis of liability. In both doctrine and case law it has been stated that the responsibility of the Treasury concerned state officials both in the sphere of the empire and dominion. The condition of this responsibility, however, was that the damage was done in the exercise of officer activity. The literature highlights the political nature of the regulation, since the law introduced the principle of State liability, while in any other cases it refers to civil law (code of obligations $s^{9}$ ). This meant that the principle of State responsibility was the principle of guilt. The victim had to prove in the process that the conservation officer in the exercise of his function was culpable. At the same time it should be noted that the

See: E. Bagińska, Odpowiedzialność odszkodowawcza.., p. 146 and following, also literature quoted therein. Quoted after E. Bagińska, Odpowiedzialność odszkodowawcza..., p. 148

C 226/50, OSN 1952, No. 2, item 33

Journal of Laws No. 54, item 243 with further amendments.

Regulation of the President of Poland dated 27.10.1933, Code of obligations, Journal of Laws No. 82, item 599. 
adopted design, according to which the State is responsible for damage caused by its officers when carrying out their activities means that the state is responsible for an act of someone else, and not for their own acts. A consequence of this is furtherreaching, namely in that the Act of 1956 had not broken the rule: King can't do wrong. The State is responsible for the actions of its officers, their behavior causes injury, while the State still may not be the perpetrator of the injury, the action cannot be impaired, cannot be an anomaly. It was evaluated positively that victims' right to claim compensation for personal injury suffered in the absence of grounds for State liability under the Civil Code was introduced (Art. 5 of the Act). Alignment of the loss was possible if there was a principle of equity in favor of it. The provision, for example, mentioned the loss of the ability to work or difficult material situation. In practice, its use was limited to situations where the injury was inflicted as a result of actions taken to protect the public interest, such as vaccination. ${ }^{10}$

The Law Art. 4, limited liability of the state in case of a decision or order. It was necessary to prove a qualified guilt, as determined under criminal or disciplinary proceedings. The solution adopted in the Act has been incorporated into the Civil Code in Art. 417-421, located within the tort. In 1996, due to the amendment of the Civil Code, protection of the individual has been extended to a situation where the damage was caused by a local government unit, the provisions of Art. 4201 and 4202 CC, were added.

The general standard of liability of the Treasury was Art. 417 of the Civil Code. Other provisions constituted a lex specialis in relation to 417 of the $\mathrm{CC}$. The equivalent of Art. 4 of the Act, was Art. 418 of the Civil Code and Art. 5 - Art. 419 of the CC.

The provision of Art. $417 \S 1$ of the CC, stated that the State is liable for damage caused by a state officer in the implementation of activities entrusted to him. In view of the vague wording of the provision in the doctrine and jurisprudence there appeared doubt as to the conditions of liability of the Treasury if it is a standalone provision, or perhaps merely a declaration of the State Treasury, and for the implementation of this declaration it is necessary to apply other rules of tort liability. ${ }^{11}$

The concept of independence of Art. 417 CC, was approved by the Supreme Court in the resolution of the full composition of the Civil Chamber of 15.02.1971 - justice and jurisprudence guidelines on the liability of the Treasury and state legal

Also according to the later prevailing views, on the base of art. 419 of CC, being an equivalent of art. 5, see: Resolution of the Supreme Court dated 15.2.1971, III CZP 33/70, OSNC 1971, No. 4, item 59, Judgment of the Supreme Court dated 20.8.1968, II CR 310/68, OSNC 1969, No. 2, item 38 with a gloss of M. Sośniak, OSP 1969, No. 3, item 67, Judgment of the Supreme Court dated 25.9.1969, II CR 353/69, OSNC 1970, No. 6, item 116, see A. Szpunar, Odpowiedzialność Skarbu Państwa na zasadzie słuszności, PiP 1970, No. 2, p. 232. 
persons. ${ }^{12}$ In that resolution, the Supreme Court has interpreted the laws of the State Treasury. The court held that the liability of the Treasury is a separate type of liability in tort scheme. The literature indicates that it gave rise to the stratification of tortious liability and certain provisions were used, depending on who is the subject of liability, even if the damage was done in similar circumstances. ${ }^{13}$ The Treasury responded to the Art. 417 et seq. both when an action that causes the damage could have been classified into the realm of empire and dominion.

The wording of the provision has not fully identified conditions of liability, which could raise doubts of interpretation. The Supreme Court stated that the necessary condition of liability is the fault of the officer. The State Treasury shall be liable in responsibility for someone else's act, and a feature which justifies the responsibility of the Treasury was culpable conduct of a state officer. Demonstration of any degree of a government official's guilt resulted in the responsibility of the Treasury.

Despite indications of guilt, it was assumed that in the case of liability on the base currency. Art. 417 of the Civil Code, it is not essential if the officers were at fault, if it is proved that the guilt was caused by one of the members of a specific team of officers. The essence of this argument in the judicial practice denotes that only illegality of the behavior of an unidentified officer has been determined. In the absence of individualization of the perpetrator it was not possible to determine the subjective elements in the form of guilt. This structure corresponds to the concept of "anonymous guilt". That was the evidence which could undoubtedly facilitate the victim, who had to demonstrate in the process that the damage remained in the normal causal connection with the conduct of the officer who carried out their duties. In practice, anonymous guilt has been used in particular in cases of responsibilities of public healthcare centers.

The State Treasury was responsible for the actions of public officials. The definition of an officer was based on the principle of example listing included in Art. $417 \S 2$ of the Civil Code. In its understanding, state officers are: employees of public authorities, government or the national economy, moreover, persons acting on behalf of these organs, persons appointed by election, judges, prosecutors and soldiers of the armed forces. It should be noted that the case law applied the broad interpretation of the provision for the benefit of victims. A state officer was a teacher, doctor, police officer, an employee of the National Health Service, deputy, senator, juror, but also, for example, a policeman called for help when chasing a criminal. In the guidelines of 1971, the Supreme Court stated that the wording of the rule allows to consider as public officials all persons who, regardless of the type and nature

12 III CZP 33/70, OSN 1971, No. 4, item 59.

13 E. Łętowska, Stratyfikacja odpowiedzialności deliktowej, PiP 1971, No. 6, p. 943 
of their functions, remained with the state authorities or public corporation in any employment relationship.

The Supreme Court acknowledged in the guidelines that the Treasury will be liable under Art. $417 \S 1 \mathrm{CC}$, under the following conditions:

1) damage caused by a State officer within the meaning of Art. $417 \S 2$ of this article;

2) wrongful act or omission of an officer;

3) normal causal link between the act or omission of the officer and the damage;

4) injury caused by the officer entrusted due to their feasibility step.

Specific provision in relation to Art. $417 \mathrm{CC}$ was Art. $418 \mathrm{CC}$, which provides for the responsibility of the Treasury for the damage caused by a ruling or order. It limited the liability of the Treasury, introducing qualified guilt. The victim had to demonstrate that at the release of the decision or order there was a breach of the law which should be prosecuted in criminal or disciplinary proceedings, and in addition, a State officer's fault also had to be found in the criminal appeal, disciplinary decision or declared by the superior of the perpetrator of the injury. Primarily the requirement to prove a double-qualified fault caused that Art. $418 \mathrm{CC}$, in practice, did not have wider application.

If the injury was caused by faulty execution of orders or judgments, the responsibility of the Treasury was based on Art. 417 § 1 CC, rather than Art. 418 CC. It should be emphasized that the Supreme Court in the 1971 guidelines, said that broad interpretation should not be given to the meaning of the term "decision or order". This was of great importance to the victim because of the dim possibility of seeking damages for injury when the source of injury was not an individual act (judgment of the court, administrative decisions). There were no grounds to claim compensation for a defectively issued normative act.

The Treasury responded on the basis of Art. $418 \mathrm{CC}$, when the following conditions were met:

- damage resulting from a decision or order

- adequate causal link between the adoption of a decision or order and the damage

- ruling or order was in violation of the law prosecuted by the criminal or disciplinary proceedings 
- fault of the person responsible for the detriment has been established by criminal conviction, disciplinary action or recognized by the organ superior to the injury's perpetrator.

Specific provision in relation to Art. 417 CC was also Art. 419 CC. It stipulated the responsibility of the Treasury on an equitable basis. The victim could claim compensation and satisfaction if the conditions of Art. 417 CC and Art. 418 $\mathrm{CC}$ were not met and the victim suffered bodily injury or health damage. Thus, compensation could be made even with no fault of the officer, but the officer's act had to be considered unlawful. Only personal injury was subjected to compensation and the rules of social relationships had to support the compensation (important moral considerations). The Act, in particular, mentioned the victim's inability to work or a difficult material situation. The principles of fairness decided not only of the granted compensation, but also of its amount. Only part of the damage could be compensated for to the victim.

On the basis of Art. $419 \mathrm{CC}$, the victim could claim compensation for all costs 14 in connection with personal injury and harm to health, including primarily the cost of medical care, pensions, compensation..$^{15}$ In case of death of the direct victim, persons close to the victim were entitled to claim reimbursement of medical expenses, pension, compensation and reimbursement of funeral costs if they covered them themselves. ${ }^{16}$

Premises of liability which had to be shown in the process were:

- personal injury,

- the unlawful conduct of an officer in the performance of his duties,

- adequate causal connection between the injury and the conduct of an officer,

- legitimacy of awarding damages under the principles of social relationships.

In practice, the judicature departed from the obligation to prove causation in accordance with Art. $361 \S 1$ CC. It accepted as sufficient the causal link, which facilitated the situation of the victim. The Supreme Court in appeal dated 09/05/1969 stated that at the responsibility of Art. $419 \mathrm{CC}$, it is enough to adopt such a link which indicates that the damage is the result of an officer's conduct, and considerations of fairness are in favor of its compensation. The action does not necessarily aim

\footnotetext{
14 See more in: J. Matys, Szkoda na osobie - uwagi na tle art. 444 kc., Monitor Prawniczy 2004, No. 10 , p. 457 and following, A. Szpunar, Odszkodowanie za szkodę majątkową. Szkoda na mieniu i na osobie, Bydgoszcz 1998

15 See more in: J. Matys, Model zadośćuczynienia z tytułu szkody niemajątkowej w Kodeksie cywilnym, Warszawa 2010, M. Wałachowska, Zadośćuczynienie pieniężne za doznaną krzywdę, Toruń 2007

16 See more in:A. Szpunar, Wynagrodzenie szkody wynikłej wskutek śmierci osoby bliskiej, Bydgoszcz 2000.
} 
to cause damage; it is aimed at stating that without this action the damage could not occur. Such a relationship appeared in a case decided by the Court where the plaintiff would not have suffered injury if she had refused the vaccination. ${ }^{17}$

Interpretation of the liability provisions of the Treasury for the damage caused by State officials approved in doctrine and law, was generally accepted until the entry into force of the Polish Constitution of 2 April 1997, i.e. until 17 October 1997. The provision of article $77, \S 1$ of the Constitution, states that "everyone has the right to compensation for damage which was caused by an unlawful act of public authority". In the doctrine there were doubts about the constitutionality of the liability provisions of the Treasury. ${ }^{18}$ In particular, the condition of guilt set in the 1971 guidelines of the Supreme Court in Art. 417 CC, drew attention. A prerequisite of liability in accordance with Art. $77 \S 1$ of the Constitution, is being unlawful. Thus, as defined by the Supreme Court in 1971 and used in the case-law claiming damages under Art. 417 \& $1 \mathrm{CC}$, was more difficult for the victim than as suggested in the conditions stated in the Constitution, which meant non-compliance of the provisions of the responsibility of the Treasury established in the Civil Code of the Basic Law. ${ }^{19}$

The dispute was settled by the Constitutional Court. In its ruling of December 4, 2001, the Constitutional Court held that Art. 418 CC is unconstitutional, and Art. 417 understood in this way says that the State is liable for damage caused by unlawful action of a public servant in the performance of activities entrusted to him, is in accordance with Art. $77 \S 1$ of the Constitution. Thus it was necessary to change the interpretation of the provision. The Court held that Art. $417 \mathrm{CC}$, did not contain evidence of the State Treasury's responsibility for the actions of public officials which did not comply with the Constitution.

The broad interpretation of Art. $417 \mathrm{CC}$ established in the guidelines of the Supreme Court, 1971, was incompatible with Art. $77 \S 1$ of the Constitution. Strict, literal interpretation of the former Art. $417 \mathrm{CC}$, points to its compliance with Art. 77 $\S 1$ of the Constitution.

II CZ 223/69, Lex 6554 .

P. Granecki, Odpowiedzialność cywilna Skarbu Państwa za szkodę wyrządzoną działaniem swojego funkcjonariusza (wybrane zagadnienia), Palestra 2000, No. 11, p. 16, E. Łętowska, W kwestii zmian przepisów o odpowiedzialności za szkody wyrządzone działaniem władzy publicznej, PiP 1999, No. 7, p. 75, M. Kępiński, R. Szczepaniak, O bezpośrednim stosowaniu art. 77 ust 1 Konstytucji, PiP 2000, No. 3, p. 79, M. Safjan, Odpowiedzialność państwa na podst. art. 77 Konstytucji RP, PiP 1999, No. 4, p. 3, M. Safjan, Jeszcze o odpowiedzialności Skarbu Państwa na podst. art. 77 ust. 1 Konstytucji (W odpowiedzi Prof. A. Szpunarowi), PiP 1999, No. 9, p. 79, A. Szpunar, O odpowiedzialności odszkodowawczej państwa, PiP 1999, No. 6, p. 86, A. Szpunar, Kilka uwag o odpowiedzialności odszkodowawczej państwa, Rejent 2001, No. 2, p. 121.

See: S. Wronkowska, W sprawie bezpośredniego stosowania Konstytucji, PiP 2001, No. 9, p. 3, also see: Judgment of the Supreme Court dated 15.5.2000, II CKN 293/00, OSNC 2000, No. 11, item 209 with the glosses of E. Łętowska, OSP 2000, No. 12, item188 and P. Granecki, Palestra 2001, No. 11-12, p. 225, A. Mączyński, Bezpośrednie stosowanie Konstytucji przez sądy, PiP 2000, No. 5, p. 3, A. Szpunar, O odpowiedzialności odszkodowawczej ..., PiP 1999, No. 6, p. 86. 
For the provision of Art. $417 \S 1$ of the $\mathrm{CC}$ to remain in compliance with the Constitution, it had to be assumed that since the Basic Law's entry into force, the premises of liability of Art. $417 \S 1$ of the Central Committee were:

- damage caused by a State official in the performance of his duties;

- the unlawful conduct of the officer

- adequate causal link between the unlawful conduct of the officer and caused injury to the victim.

However, the Constitutional Court ruling did not remove all doubts about the interpretation of Art. $417 \S 1$ CC. Disputes mainly concerned the question whether the condition of illegality should be used only if the behavior of the officer belonged to the realm of the empire and for the sphere of dominion the guilt of the officer or non-compliance with the law, which is a prerequisite of liability of the Treasury, remains to be proven, both in its dominion and empire. ${ }^{20}$

As a result of changes in the interpretation of Art. $417 \S 1 \mathrm{CC}$ lining of Art. 419 $\mathrm{CC}$ was also changed. The Constitutional Court pointed out that the condition of the State Treasury to Art. 419 CC after the entry into force of the Constitution is that the injury was proven to be the result of lawful behavior of a public servant.

Once again, it should be noted that Art. $418 \mathrm{CC}$ was declared unconstitutional and therefore should not be applied to events arising after 17 October 1997. The effects of Constitutional Court's ruling of 4 December, 2001, concerned the legal status arising after the Constitution's coming into force. This date was also indicated in another decision of the Constitutional Court of 23 September 2003. ${ }^{21}$

2. The general rule of responsibility of the Treasury on the grounds of the Polish Civil Code

On 17 June 2004, Parliament passed an amendment adapting the rules of the State Treasury's responsibility for exercising public authority according to Art. 77, par. 1 of the Constitution and to the recommendations of the Council of Europe $(\mathrm{Nr}$ $\mathrm{R}$ (84). The Act came into force on 1 September 2004. It revoked previous Articles $417 \mathrm{CC}, 418 \mathrm{CC}$ and $420 \mathrm{CC}$ and in their place new provisions of Art. 417, Art. $417^{1}$ and Art. 4172 were introduced.

W. Czachórski, Zobowiązania. Zarys wykładu, Warszawa 2007, p. 261, Z. Banaszczyk (in:), J. Pietrzykowski (ed.), Kodeks cywilny. Komentarz, t. I, Warszawa 2005, p. 1109-1110, G. Bieniek, Odpowiedzialność Skarbu Państwa za szkody wyrządzone przez funkcjonariuszy po wyroku Trybunału Konstytucyjnego z dnia 4.12.2001 r., Przegląd Sądowy 2002, No. 4, p. 3 and following, A. Górski, Artykuł 417 kc. - przepis niewłaściwie interpretowany czy niekonstytucyjny, Przegląd Sądowy 2003, No. 1, p. 40 and following.

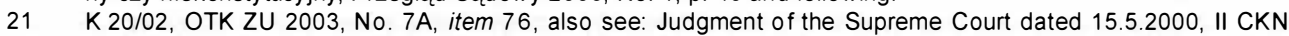
293/00, OSNC 2000, No. 11, item 209, Judgment of the Supreme Court dated 9.10.2003, I CK 150/02, OSNC 2004, No. 7-8, item 132. 
The literature states that the amendment of the Civil Code of the State Treasury for the damage caused by exercising public authority, includes three significant changes in comparison to the legal state before the amendment. The first is ideological, and the next two are of systemic nature. ${ }^{22}$ The first amendment should be particularly emphasized since it means the total departure from the rules previously in force and is a novelty in the entire system of accountability of public authority in Polish civil law. This change affects the structure of the State Treasury's responsibility. Within its framework, in order to better identify its essence, we can distinguish two aspects, namely the adoption of the State Treasury's responsibility for the damage done by an officer and the other one, which is consistent with the first, a departure from the personal relationship of injury to the officer of the state in favor of a functional relationship - the exercise of public authority. Prior to the amendment of the Civil Code of 17 June 2004, in full force was the rule: "King can't do wrong". Malfunction is not typical of public authority, the damage arose as a result of its improper performance by a state official understood in practice very broadly. This official act or omission was a damaging event. In the previously approved scheme perpetrator was an officer of the injury, so the Treasury was responsible for the act of someone else. Currently, according to the construction of Art. 417 CC, responsibility concerns only someone's own acts. The Treasury, a local government unit or a state legal person performing a public authority under the law shall be liable for damage caused by the exercise of public authority. Emphasis was placed on functional criteria rather than subjective. Indicated in the wording entities will be held liable if they were the direct perpetrators of the damage. It is not important to identify the individual and his classification as a public servant in order to assign responsibility to the Treasury. The Treasury and other appropriate entities are liable for damage caused by the exercise of public authority, regardless of who was the direct perpetrator of the injury. It is also possible to assign liability where the damage was caused by a person with no formal links with the institution, for instance, a passerby called for help by a policeman chasing a thief. It is sufficient to establish a causal link between the exercise of public authority and the damage. A key element is the exercise of public authority is either law or an order. Where there is a sovereign entity subordination to civil government, the performance of which the entity can not object, there will arise a liability of the Treasury (local government unit, legal persons performing public authority under the law), if the result of the exercise of public authority will be detrimental. The Treasury will be responsible for their own act, ${ }^{23}$ for exercising public authority, for actions which are associated with the State's well-being. In the previous legislation the Treasury was responsible for the culpable (until the entry into force of the Constitution) conduct of

Z. Banaszczyk (in:) A. Olejniczak (ed.), System Prawa Prywatnego, Prawo zobowiązań - cz. ogólna, t. VI, Warszawa 2009, pp. 777-781

23 See: M. Safjan, K.J. Matuszyk, Odpowiedzialność odszkodowawcza..., p. 32 
a public servant, and not for actions that are the State's matters. It can be concluded that an officer has behaved badly, causing injury, but the Treasury only bears the consequences of this behavior and it has not caused the damage itself. The doctrine states that the change is related to the Polish accession to the European Union and the necessity to adjust Polish law to the standards required by the Community. ${ }^{24}$ It is also indicated that the provisions governing the liability of the Treasury passed to the Polish law underwent a significant evolution. At the beginning, the principle of full irresponsibility was implemented, then it was departed from in different ways to have a rule of full responsibility now. ${ }^{25}$

Systemic changes regard in particular the formation of the State Treasury on the premise of unlawfulness on the basis of objective criteria. The liability premise of Art. $417 \mathrm{CC}$, is not the fault of the entity performing public authority, but unlawful exercise of public authority. It was accepted that the principle of accountability is the principle of risk here, not the principle of guilt. ${ }^{26}$ At the same time it should be noted that the concept of illegality is not identical with the concept of unlawfulness under the civil law. In terms of civil law, the unlawfulness is generally understood as the behavior of non-compliance with the law and rules of social conduct (principles of fairness, moral and ethical standards). ${ }^{27}$ However, the illegality is a narrower concept, covering only the behavior of non-compliance with the legal standards in terms of positive law (law is what is included in the act); it is incompatible with the norms of positive law in constitutional terms.

Withdrawing from the premise of fault occurred, according to the ruling of the Constitutional Court of 4 December 2001, upon the entry into force of the Constitution. Since that time, in the cases of causing damage, the victims have not had to prove guilt of a public servant in a trial. It should be noted that the departure from the principle of fault is a more severe liability of the Treasury, which facilitates the procedural situation of the victim. At the same time it can be postulated that the introduction of conditions for non-compliance with the laws of behavior rather than the condition of illegality in the classic civil law approach is a positive change. In this way, the responsibility for damage resulting from the exercise of public authority is founded on a clear, predictable and transparent basis. It cannot be assumed that the unlawfulness understood as a contradiction with the laws and rules of social interaction is predictable, since the principles of community life are vague and

24 Z. Banaszczyk (in:) A. Olejniczak (ed.), System Prawa Prywatnego..., p. 780.

25 Ibidem, s. 780.

26 See also: other opinions regarding the principles: M. Kaliński, Szkoda na mieniu i jej naprawienie, Warszawa 2008, p. 109 and following, J. Kremis, Skutki prawne w zakresie odpowiedzialności odszkodowawczej państwa na tle wyroku Trybunału Konstytucyjnego, PiP 2002, No. 6, p. 40, Z. Radwański, Odpowiedzialność odszkodowawcza za szkody wyrządzone przy wykonywaniu władzy publicznej w świetle projektowanej nowelizacji Kodeksu cywilnego, Ruch Prawniczy, Ekonomiczny i Socjologiczny 2004, vol. 2, p. 14

27 See also: a standpoint of K. Pietrzykowski (in:) M. Pyziak-Szafnicka (ed.) Odpowiedzialność cywilna. Księga pamiątkowa ku czci Profesora Adama Szpunara, Kraków 2004, p. 167 and following. 
change over time. On the one hand, they may extend the scope of a situation for which the Treasury will be liable, on the other, however, they may inflict confusion, cause a different outcome in comparison to similar situations in which different courts adjudicate.

The second change of a systemic character relates to, without any doubts and disputes, including strict liability under Art. $417 \S 1 \mathrm{CC}$, only the imperious sphere - the empire. In situations where the State acts in the sphere of dominion, in the economic sphere, it is liable like any legal person, based on the general provisions of tort liability.

In accordance with Art. $417 \S 1 \mathrm{CC}$, the Treasury shall be liable for an unlawful act or failure in the exercise of public authority. This standard is an independent basis for liability. Premises of liability are: harm, unlawful exercise of public authority and an adequate causal link between the damage and the causative event, i.e. unlawful exercise of public authority.

It should be emphasized that under Art. $417 \mathrm{CC}$ a natural person shall not be liable. ${ }^{28}$ The direct perpetrator of the damage - a natural person, a person employed in staciones fisci at the Treasury - may incur personal liability under other provisions of tort liability.

It seems that most of the difficulties of interpretation may be related to the concept of the exercise of public authority. In order to clarify this concept one should refer to the Constitution. The Constitutional Court in the appeal dated to 12/04/2001 noted that the concept of a public authority within the meaning of Art. 77, par. 1 of the Constitution covers all the authorities in the constitutional sense, namely the legislative, executive and judicial. It is not sufficient, though. The provision of Art. 163 of the Constitution, states that exercising public authority can be also done by a local government unit. Additionally, taking into account the subjective meaning of the term public authority, it is clear that the exercise of public authority may be given to other entities, institutions.

Due to the fact that the scope of the subjective concept of the term public authority is not clear and legal qualification cannot be made on this basis and without doubt say that every aspect of a particular legal subject's activity is in accordance with the premise of executing public authority of Art. $417 \mathrm{CC}$, one should make use of the objective interpretation of the term public authority. The Constitutional Court, in support to the ruling of 4th December 2001, indicated that the exercise of public authority, "as a rule, though not always, is connected with the possibility of legal shaping of an individual situation. This applies to an area where there may be a violation of the rights and freedoms of individuals by the public authority".

It seams questionable in a case of notary public, exercising public authority in some cases. 
Authority executing in the colloquial sense, sociological or even legal, means possibility of implementing coercion against specific persons. However, the literature indicates that "the action of public authority" can not be confined to the realm of strictly understood empire, but it includes all forms of public tasks, even without the element the authoritative influence on the individual's legal situation..$^{29} \mathrm{G}$. Bieniek, believes that the exercise of public authority covers activities under the Constitution and other legislation, the execution of which usually involves the possibility to legally shape an individual's situation. It is an action in the area in which the rights and freedoms of an individual may be violated by public authority. ${ }^{30}$ It is also indicated that the state is carrying out public tasks not only when there is a possibility of shaping legal status of an individual, but we can also talk about exercising public authority when the implementation of public tasks is not of an authoritative character. It is also noted that this sphere of the State's activity is not imperious when it is done properly, but when done incorrectly, the individual without power and means of protection is put in a situation of direct coercion ${ }^{31}$. Consequently, the doctrine states that this concept should include not only the issue of acts of governmental authority in the sphere of the empire, but also other acts and activities characteristic of public authorities, including acts of organization and order, for example, the security of mass events, marking public roads, ${ }^{32}$ beating a citizen by a police officer, a prisoner - by prison guards, in the sphere of health protection, without any doubt, where there is specific statutory compulsion of treatment, mandatory vaccinations. ${ }^{33}$ In the sphere of education there is a sovereign decision on admission to primary school, the decision to delist students, postponement of compulsory schooling.

It is important to underline the fact that the amendment of Art. $417 \mathrm{CC}$, limited the range of situations in which the State took responsibility on the basis of Art. 417 CC. The Treasury's detrimental action, which can be classified into the realm of dominion, gives rise to liability under general principles. This is a significant change compared to the previous legal situation. Under the previous legislation in the public health care in case of a medical error, the Treasury was responsible under the former Art. 417 CC. $^{34}$ However, under the current rules of liability Art. 430 or Art. 429 $\mathrm{CC}$ will give legal base in the case of a contracted physician, while the hospital is released in the latter case from liability by proving that they ordered the execution

Z. Banaszczyk (in:) A. Olejniczak (ed.) System Prawa Prywatnego ..., p. 790 and literature and judgments quoted therein, especially E. Bagińska, Odpowiedzialność.., p. 258 and following.

G. Bieniek (in:), G. Bieniek (ed.), Komentarz do Kodeksu cywilnego. Księga III, t.1, Warszawa 2006, p. 271272.

Z. Banaszczyk (in:) A. Olejniczak (ed.) System Prawa Prywatnego ..., p. 791

M. Safjan, K.J. Matuszyk, Odpowiedzialność odszkodowawcza..., p. 38, W. Czachórski, Zobowiązania..., p. 263-264.

See: E. Bagińska, Odpowiedzialność..., p. 296 and following

See more in: E. Bagińska, Odpowiedzialność..., p. 278 and following. 
of activities to a specialist, which means that the victim is in a worse situation. It is more difficult to obtain compensation from an individual than an organized entity.

Another condition which the victim has to prove is damage. Pursuant to Art. 417 $\S 1 \mathrm{CC}$, both economic forfeiture (loss and lost profits) and non-pecuniary damage (harm) are subject to compensation. ${ }^{35}$ It is worth noting, however, that compensation for non-pecuniary damage in the Polish civil law is due in these statutory cases: when the harm arises as a result of a breach of casualty's personal rights (Art. 445 CC, Art. 448 CC) or as a result of the death of a close relative (Art. $446 \S 4$ CC). The choice of natural remedy or restitution, payment of compensation shall be decided by the victim according to Art. $363 \S 1 \mathrm{CC}$.

The Treasury will be liable if the victim proves that there is an adequate causal link between the injury and the causal event, i.e. the exercise of public authority. On the background of Art. $417 \S 1 \mathrm{CC}$, in practice there are no departures from the theory of adequacy from Art. $361 \S 1$ CC. The Supreme Court in the decision dated to 27 th November 2002, stated that the normal causal link between the incident and the injury occurs when in a given set of relations and conditions and in the ordinary course of things, with no special circumstances, the injury is a normal consequence of such events.36 Such a conducted interpretation should be agreed with also on the background of causation as a premise of Art. $417 \mathrm{CC}$.

\section{Liability for damage caused while performing tasks within public authority}

A new solution introduced by an amendment to the Civil Code dated to 16 th June 2004, is regulating the liability of the Treasury in case of an order by agreement of the tasks within public authority (Art. $417 \S 2 \mathrm{CC}$ ). Entities that may issue an order to carry out tasks within public authority shall be indicated in Art. 417 § 1 CC. It should also be noted that the order may be made only for the local government or a legal person, therefore, ordering the tasks of public authority to a natural person is ruled out.

It is important to point out the consequences of the solution adopted in Art. 417 $\S 2$. The first one is the joint responsibility of both the commissioner and the contractor. The commissioner shall not relieve from the strict liability incurred by the contractor of public authority by ordering its performance to the entity listed in the Act. Solidarity liability means that the victim may choose a person against whom licznej w noweli do Kodeksu cywilnego, Przegląd Sądowy 2004, No. 9, p. 33, who treats pecuniary damage as an impediment of liability according to art. $417 \S 1$ of CC, excluding non-pecuniary damage. I CKN 1215/00, Lex 78330 with a gloss of A. Jaroszyński. OSP 2004, No. 1, item 3. 
to issue the claims, which gives him a higher probability of settling the claims. At the same time a statutory basis for solidarity has been created. ${ }^{37}$

A second consequence is to establish a strict, based on the risk principle, liability of the entity performing the tasks of public authority. Both the contractor and commissioner are liable if the damage was caused by the unlawful exercise of public authority and there is an adequate causal link between the exercise of public authority and the resulting damage. In addition, the victim must prove the fact of entrusting the implementation of actions by the commissioner. Liability is based on the criterion of functional, just as in Art. $417 \S 1 \mathrm{CC}$, anyone who exercises public authority bears more severe liability. The literature indicates that the responsibility of the orderer is a responsibility similar to that formed in Art. 474 CC (debtor's liability for third party performing the obligation $)^{38}$.

The order on the basis of agreement can occur only when such a possibility is predicted by a provision of the law. The agreement is not of the civil law type, but administrative law and, therefore, is allowed only in cases provided for by law, the principle of freedom of contract is excluded in public and legal relations. Delegating tasks of public authority is based on the agreement which requires the consent of both parties. In agreeing to the execution of tasks from the sphere of the empire, the entity at the same time assumes strict liability for damage incurred in the performance of these activities. The principle of liability is the same as provided for in Art. $417 \S 1$ $\mathrm{CC}$ in relation to sovereign entities performing duties on legal basis. ${ }^{39}$

\section{Liability of the State Treasury for prescriptive acts and individual adjudications}

The amendment act introduced significant changes to the scope of liabilities of the public authority organs for prescriptive acts and individual adjudications. The legislative basis was Art. $4171 \mathrm{CC}$, that is lex specialis to Art. $417 \mathrm{CC}$. The construction of the regulation was such that the source of damage included not only actions i.e. issuing a prescriptive act or individual, final decision or legally binding adjudication, but also nonfeasance i.e. not issuing a prescriptive act or adjustment in an individual case. This is the first significant change in comparison to the legislation binding before the establishment of the Polish Constitution. The former Art. $418 \mathrm{CC}$, equivalent of the current Art. $4171 \mathrm{CC}$, referred to the responsibility for the positive activities only, for actions taken excluding nonfeasance. The second difference that is 
worth noticing, regards the subject scope of liability, which according to the previous regulation defined the State Treasure responsible for the individual adjudications only. The third change incorporates the general substance of the public authority organs' amended liability for damages and regards the basic premises of liability, i.e. against the law.

The cases indicated in Art. 4171 restrict application of Art. 417 CC. Not every defect of a prescriptive act, legally binding adjudication or final decision can constitute the basis for liability. The premise of unlawfulness under Art. $4171 \mathrm{CC}$ has to be therefore verified according to appropriate proceedings, the procedure defined by the proper regulations. The Compensatory Court - the court examining the case can not therefore by itself define defectiveness of a prescriptive act or unlawfulness of a binding court adjudication or a final decision, but it has to base its verdict on the case on the former definition of the fact made with appropriate proceedings - prejudicial procedure, so called "pre-judgment". An exception to the obligatory prejudgment is Art. $4171 \S 4$ defining the liability for not issuing a prescriptive act. In this circumstance the court hearing the case adjudicates whether not issuing the prescriptive act was lawful.

The regulation under Art. 4171 consists of four norms. In each of them the premise of the liability is the damage, the adequate relation of the damage reason and the causative event and unlawfulness of the event that caused the damage. It seems that under Art. 4171 only the property damages are compensated. Polish civil law allows claims for non-material damage reparations only in cases that the regulation provides for: in case of personal rights violation and in case of a close relative death. It is hardly possible that this kinds of damages resulted from issuing or non-issuing a prescriptive act or individual adjudication happen in practice to the aggrieved party. Additionally, the literature indicates that to receive compensation for lost benefits the aggrieved party has to prove that in this specific case the damage would be caused, indicating only the potential possibility of benefits is insufficient. ${ }^{40}$

The regulation under Art. $4171 \S 1 \mathrm{CC}$, defines the liability for the damage caused by issuing a prescriptive act against the norm higher in the hierarchy. The prescriptive act under this regulation is the Constitution, ratified international agreement, order, directive, but also local law rule. The Constitutional Tribunal has the competence to adjudicate the compliance of the lower rank regulation to the higher rank ones. Therefore the pre-judicial procedures in this case will take place at the Constitutional Tribunal. An exception is adjudicating the compliance of local law rule to the higher rank regulations. The Administrative Court is competent in this case. Doubts emerge on the issue of adjudicating the compliance of Polish law to the 
Union regulations - which organ: Polish Constitutional Tribunal or the European Court of Justice is competent to adjudicate the issues ${ }^{41}$.

The defendant should be the subject that issued the prosecuted norm. The State Treasure is liable for the laws enacted by the state organs, acts and directives.

The regulation under Art. $4171 \S 4$ defines the liability for so called nonfeasance that is not issuing a prescriptive act, but only in the situation that issuing the act is allowed by law. Not issuing the act is unlawful and constitutes the event causing damage. Issuing the prescriptive act has to derive from the law, not from axiological, general principles of the legal system. Simultaneously, the date of the prescriptive act issuing should also be indicated by law.

It is indicated in the literature that only the prescriptive acts defining the legal status of the civil law subjects can be prosecuted. ${ }^{42}$

The characteristic feature is no requirement of pre-judgment.

The State Treasury shall be liable exclusively for not issuing the prescriptive acts that the state organ was obliged to issue.

Regulation under Art. $4171 \S 2 \mathrm{CC}$ refers to the situation when the damage is caused by unlawful issuing of the final decision or legally binding order, it does not include the cases when the cause of damage is improper execution of the decision or the order. Unlawful execution undergoes Art. $417 \S 1$ CC.

The above regulation defines the liability of the State Treasury and other subjects in two situations. The first one when the source of damage was issuing the adjudication or decision against the binding law. The second when the damage resulted from issuing the adjustment or decision legally based on the prescriptive act against the Constitution, act or ratified international agreement, and therefore not the final decision or adjustment itself was correct and officially in compliance to the law but the legal basis was incorrect.

The subject entitled for the compensation will be anybody who aggrieved damage resulting from the decision or order against the law. It is be assumed that the compensation can be claimed by any subject legally able to act as a party in the court or administrative proceedings.

The requirement is that the cause of damage which the State Treasury is liable for should be the legally binding adjudication or final decision. The decision is final 
if there is no entitlement to appeal in the administrative proceeding. The court order is legally binding if there is no appeal entitlement or other prosecution means.

The regulation does not require any degree of incompliance to the law e.g. gross. Each decision or adjustment, disregarding the level of incompliance to the law, makes the basis for claiming compensation.

The legislators require everyone who claims damage compensations under Art. $4171 \S 2 \mathrm{CC}$, to present the pre-judicial adjudication confirming the binding adjudication or final decision to be unlawful. The aggrieved can also present the pre-judicial adjudication that confirms the legal basis of the individual act to be unlawful.

Regulation under Art. $4171 \S 2 \mathrm{CC}$ does not itself define the course of defining the adjudications and decisions unlawful. However, there are indications concerning the possibility of finding reference to the procedural instruments that depend on the kind of proceedings and the character of adjudication i.e. if the compensation claim is based on the adjudication in the civil case, the pre-judicial adjudication should also be defined in course of the civil proceedings. In the civil proceedings the prejudgment character concern adjudications made in two basic kinds of proceedings: the proceedings instituted on a complaint to reopen the case that was closed with a binding verdict (Art. $3990416 \mathrm{CPC}$ ) and the proceedings regarding a complaint to qualify unlawfulness of a binding court adjudication (Art. 4241 - art. 42412 CPC). Also the adjudication in cassation complaint proceedings can be the pre-judicial proceedings.

Character of the pre-judgment in penal proceedings concern the adjudications made in case reopening proceedings (Art. 540 and next PPC) and cassation proceedings (Art. 518 and next PPC).

In the administrative proceedings the pre-judgment character concerns also proceedings to declare invalidity that may take place under Art. 172 of Administrative Court Proceedings regulations and proceedings to reopen the proceedings 270 ppsa (Law on proceedings before the courts).

In the case when the damage resulted from issuing an adjudication or decision incompatible with a hierarchically higher norm, the preliminary ruling will be an adequate decision of the Constitutional Court and also a verdict of the Administrative Court in case of invalid declaration of local law act. ${ }^{43}$

Compensative liability for not issuing a decision or adjudication when the obligation to issue them was under Art. $4171 \S 3 \mathrm{CC}$. This regulation concerns the 
liability for nonfeasance by the authority and refers to not issuing ruling acts of individual character.

An activity causing damage under this regulation means not issuing the individual act and also if issuing the adjudication took the public authority organ too much time and therefore the related subjects are liable for lengthiness of the proceedings.

The pre-judicial proceedings in this case relate to all of the court proceedings: civil, penal, administrative and executive based on the same act of 17.06.2004 concerning complaint on breaking the rights of a party to have the case adjudicated in court proceedings without any unjustified delay. ${ }^{44}$ The proceedings evaluates the promptness, correctness of the court procedure, complexity of the case. The complaint is lodged to the court that proceeds the case and the court transfers the case files immediately to the court appropriate for adjudicating the case that is the superior court. The case is then adjudicated by 3 judges and the relevant regulations are applied regarding the kind of proceedings CPC, PPC. The court can order to follow the relevant procedures. It can pronounce following the relevant procedures. It can also on demand of a party grant a compensation of 20.000 PLN.

\section{The State Treasury liability for legal damages}

Art. 4172 CC provides for the reparation of the damage which resulted from executing public authority (in accordance with law), but not in the situation when it would be unjustified to burden the effects on the aggravated party only. The State Treasury under Art. 4172 CC, is liable under the rightness rule. Moral, ethic norms support the reparation of damages made to the aggravated. The liability under the rightness rule is updated only if there is no basis for a compensation claim under general regulations and there is significant evidence for granting a compensation.

The liability evidence under Art. 4172 CC:

- lawful execution of public authority;

- damage on person

- basically relevant cause relation between the public authority act and damage

- legitimacy of granting the compensation under the rightness rule. 
The evidence under Art. 4172 CC does not include unlawfulness of the causative behavior, the regulation provides for liability for the legally done damage. Behavior of the subject executing public authority was in accordance to the regulation however, the damage was done.

The evidence of executing public authority should be understood the same way as the general formula of Art. 417 CC. It refers to activities of the State Treasury in the sphere of empire. It does not include activities irrelevant to executing the power.

Art. $4172 \mathrm{CC}$ does not include any separate rules that could modify excepting from the generally accepted in compensative liability evidence of adequate causative relation. Under the former Art. $419 \mathrm{CC}$, the adjudications were contented with the ordinary causative relation if it was justified by the rightness rule.

Restrictions under Art $4172 \mathrm{CC}$ can be observed with damage premises in comparison to the general rules formulated in Art. $417 \mathrm{CC}$. The aggravated can claim compensation but not for any form of damage done. The exclusion from compensation under Art. $4172 \mathrm{CC}$, includes the damage on property. The regulation states that if the damage was one to the person there is a possibility of full or partial reparation or compensation for non-material damage. The compensative damage can be fully or only partially repaired and the scope of compensation undergoes the rightness rule.

The acceptability of compensation claims depends on the evaluations reflecting the regards of correctness and therefore moral convictions and axiological rules established in the society.

On the evaluations regarding the rightness rule depend not only the adjudication if the compensation and reparation is granted, but also what shall be the scope of it. The evaluation depends on two criterions: those which concern the circumstance of the case: the situation that the damage was done, the reasons for activities taken, the kind of public authority's actions related to the causative event.

The second refers to the situation of an aggravated individual, his/her material and family situation, kind and scope of damage done, the level of disability to work.

On account of the function similarities of the general clauses used in regulations doctrine or judicature considerations can be applied regarding the interpretation of the social code notion. 


\section{Conclusion}

The new regulation introduced to the Polish Civil Code regarding the State Treasury liability for damages done while executing public authority, can be considered an adaptation to the market economy rules. It differs significantly from the previous one. First of all no premises for a government functionary's fault can be noticed that until 17.10.1997 the aggravated had to prove in court. It is definitely a facilitation for the aggravated. Basing the liability on the premise of unlawful activities while executing public authority deserves a positive note because of the premise clarity. However, in practice of executing the law Art. $417 \S 1 \mathrm{CC}$ can cause ambiguities. The difficulties might regard categorization of the activity as public authority execution. In the literature some opinions have already appeared that also activities which do not closely belong to the empire sphere can be categorized as public authority execution. Especially problematic seems to be liability in the system of health service, defining NHF (National Health Fund) liability. It is additionally stressed that this is a very broad liability, won't it lead to unsettling the balance between the rights of an individual to receive compensation from the state and the general public interest represented by the state..$^{45}$ Compensations paid by the State Treasure are in fact paid by citizens. Therefore, the judicature will be responsible for determining the borders of what should be categorized as execution of public authority and what will the State Treasury be liable for. The former regulation adjudications broadened the subject scope of liability under Art $417 \mathrm{CC}$, a demand can be made for socially acceptable rules and regulation on the State Treasurey liability for damages done by execution of public authority to be worked out under the updated legislation. 


\section{A NEW REGULATION ON STATE TREASURY RESPONSIBILITIES FOR THE DAMAGE DONE WHILE EXECUTING OFFICIAL AUTHORITY}

Current legislation of State Treasury responsibilities in the Polish Civil Code is in force from 1st Sept. 2004.

The literature states that the amendment of the Civil Code of the State Treasury for the damage caused by exercising public authority includes three significant changes in comparison to the legal state before the amendment. The first is ideological, and the next two are of systemic nature. The first amendment should be particularly emphasized since it means the total departure from the rules previously in force and is a novelty in the entire system of accountability of public authority in the Polish civil law. This change affects the structure of the State Treasury's responsibility. Within its framework, in order to better identify its essence, we can distinguish two aspects, namely the adoption of the State Treasury's responsibility for the damage done by an officer and the other one, which is consistent with the first, a departure from the personal relationship of injury to the officer of the state in favor of a functional relationship - the exercise of public authority.

Systemic changes regard in particular the formation of the State Treasury on the premise of unlawfulness on the basis of objective criteria. The liability premise of Art. $417 \mathrm{CC}$ is not the fault of the entity performing public authority, but unlawful exercise of public authority.

The second change of a systemic character relates to, without any doubts and disputes, including strict liability under Art. $417 \S 1$ CC only the imperious sphere - the empire.

The amendment act introduced significant changes to the scope of liabilities of the public authority organs for prescriptive acts and individual adjudications. The legislative basis was Art. $4171 \mathrm{CC}$, that is lex specialis to Art. $417 \mathrm{CC}$.

Art. $4172 \mathrm{CC}$ provides for the reparation of the damage which resulted from executing public authority (in accordance with law), but not in the situation when it would be unjustified to burden the effects on the aggravated party only. The State Treasure under Art. $4172 \mathrm{CC}$ is liable under the rightness rule.

The new regulation introduced to the Polish Civil Code regarding the State Treasure liability for damages done while executing public authority can be considered an adaptation to the market economy rules.

Key words: State Treasure liability, damage, unlawfulness, public authority execution, the imperious sphere 


\section{NOWA REGULACJA ODPOWIEDZIALNOŚCI SKARBU PAŃSTWA ZA SZKODY WYRZADDZONE PRZY WYKONYWANIU WŁADZY PUBLICZNEJ}

Obecne uregulowanie odpowiedzialności Skarbu Państwa w polskim Kodeksie cywilnym obowiązuje od dnia 1 września 2004 r.

W literaturze wyróżnia się w związku z nowelizacją, trzy istotne zmiany w porównaniu do poprzedniego stanu prawnego. Szczególne znaczenie należy przypisać pierwszej z nich, o charakterze ideologicznym. Dotyczy ona konstrukcji odpowiedzialności Skarbu Państwa jako odpowiedzialności za czyn własny; oznacza również odejście od podmiotowego powiązania wyrządzenia szkody z funkcjonariuszem państwowym na rzecz powiązania funkcjonalnego - wykonywania władzy publicznej.

Druga zmiana obejmuje przesłankę odpowiedzialności Skarbu Państwa, jaką jest niezgodność z prawem.

Kolejna zmiana łączy się ze sferą działania. Zaostrzoną odpowiedzialność na podstawie art. $417 \S 1 \mathrm{kc}$. Skarb Państwa ponosi wyłącznie za działania w sferze władczej - imperium, nie zaś w sferze dominium.

Ustawa nowelizacyjna wprowadziła istotne zmiany w odpowiedzialności organów władzy publicznej za akty normatywne oraz indywidualne rozstrzygnięcia. Podstawą prawną jest tu art. 4171 kc., który stanowi lex specialis wobec art. 417 kc.

Przepis art. 4172 kc. przewiduje natomiast naprawienie szkody, która jest następstwem wykonywania władzy publicznej w sposób zgodny z prawem, ale w sytuacji gdyby było niesłuszne aby skutki wyrządzenia szkody obciążały wyłącznie poszkodowanego.

Można uznać, że wprowadzona w polskim Kodeksie cywilnym nowa regulacja odpowiedzialności Skarbu Państwa za szkody wyrządzone przy wykonywaniu władzy publicznej przystosowała przepisy do reguł gospodarki rynkowej. 